\title{
EGG TRANSFER IN SHEEP. FACTORS AFFECTING THE. SURVIVAL AND DEVELOPMENT OF TRANSFERRED EGGS
}

\author{
N. W. MOORE* AND L. E. A. ROWSON \\ WITH AN APPENDIX BY R. V. SHORT \\ A.R.C. Unit of Reproductive Physiology and Biochemistry, \\ University of Cambridge
}

(Received $5^{\text {th }}$ March $\left.\mathrm{r} 96 \mathrm{o}\right)$

Summary. During the breeding seasons $1957-58$ and $1958-59$, a total of 280 fertilized eggs collected from Suffolk and Welsh Mountain ewes, mated to rams of their own breeds, was transferred at rates of either two or five eggs per animal to the Fallopian tubes or uterine horns of eighty Suffolk recipient ewes. Half of the recipients had been pretreated with injections of I 500 i.u. PMS in order to induce superovulation. The survival and development of transferred eggs, however, was found to be unaffected either by superovulation or by the breed of eggs transferred.

Overall prenatal mortality was divided into two periods ( $\mathrm{I}$ ) up to I 7 or 18 days and referred to throughout as embryonic mortality or loss, and (2) 17 or 18 days to term, referred to as foetal mortality or loss.

Two peaks of embryonic mortality were observed, one occurring before and the other after attachment of embryos to the endometrium. Embryonic death accounted for almost all the prenatal mortality and the majority of the loss occurred before attachment. Foetal mortality occurring later than the $\mathrm{I} 7$ th or I8th day of pregnancy was negligible.

The proportion of recipients becoming pregnant was the same in the groups which received two eggs and the group which received five eggs, but the ovum-survival rate following the transfer of five eggs was significantly lower than that following the transfer of two eggs. However, those ewes which received five eggs and subsequently became pregnant had significantly more lambs at term and normal embryos at autopsy than those which received only two eggs.

Of all the eggs transferred to the uteri and tubes, $49 \%$ and $29 \%$, respectively, developed into normal embryos or lambs. The smaller survival rate following tubal transfers was due to a higher rate of embryonic mortality.

*Present address : Department of Animal Husbandry, University of Sydney, N.S.W., Australia. 


\section{INTRODUGTION}

Egg transfer has been developed to a high degree in several species of small laboratory animals, but it was not until recently that any great success was achieved in sheep. The early work on the transfer of sheep eggs, carried out by Warwick, Berry \& Horlacher (1934), Casida, Warwick \& Meyer (1944), Warwick \& Berry (1949) and Lopyrin, Loginova \& Karpov (1950, I95I) was somewhat disappointing. In no case did any of these authors report more than $35 \%$ of ewes lambing following egg transfer. However, improvements in technique developed by Hunter, Adams \& Rowson (1955), and used extensively by Averill (r958), Averill \& Rowson (1958) and Moore \& Rowson (1959), resulted in much higher survival rates of transferred eggs. Averill (1958) reported in one experiment that twenty-four of thirty fertilized eggs transferred to sixteen recipient ewes developed into viable lambs. With survival rates of this order, it has now become possible to use egg transfer as a technique to study factors which might influence the survival and development of fertilized sheep eggs.

Among the factors which had been considered in the present study were the effect of superovulation of the recipients, breed of donors, number of eggs used for the transfer, site of transfer and prenatal mortality.

\section{MATERIALS AND METHODS}

Experimental animals. The animals used were ewes of the Suffolk and Welsh Mountain breeds, varying in age from 2 to 6 years and drawn from the flocks running under field conditions at the Animal Research Station, Cambridge. During the two breeding seasons $1957-58$ and $1958-59$, a total of 280 fertilized eggs collected from donor ewes was transferred to the Fallopian tubes and uterine horns of eighty recipient ewes. All the recipients were of the Suffolk breed, whilst the donor animals were of both Suffolk and Welsh Mountain breeds.

In order to induce superovulation, the donors were injected subcutaneously with between 800 and I 300 i.u. pregnant-mare serum gonadotrophin (PMS) on the I 2 th or I 3 th day of the oestrous cycle. The number of donors treated with PMS at any one time was determined by the number of available potential recipients expected in oestrus on the same day or over a period of $24 \mathrm{hr}$ on either side of that day. Sufficient potential recipients were synchronized naturally with the donors, and, therefore, no attempt was made to control oestrus in the recipients by progesterone therapy as described by Hunter et al. (1955).

Detection of oestrus. Donor ewes were run with active fertile rams of their own breeds and the recipients with vasectomized rams. Both the fertile and vasectomized rams were liberally coated on the brisket with a mixture of coloured raddle powder and waste oil and the ewes were inspected for raddle marks every 8 hr, at 8 a.m., 4 p.m. and 12 midnight.

Recovery and transfer of eggs. The procedures adopted for the recovery and transfer of eggs were essentially those described by Hunter et al. (1955). Fortyeight to $88 \mathrm{hr}$ after they had been first observed in oestrus, the donors were anaesthetized with Nembutal and their reproductive tracts exposed by laparo- 
tomy. Eggs were recovered by flushing the Fallopian tubes and a portion of the uterine horns with sheep serum rendered sterile by Seitz filtering and to which was added sufficient penicillin to give a final concentration of 1000 units $/ \mathrm{ml}$. The flushings were examined under a binocular microscope and any eggs present were removed together with about $0.5 \mathrm{ml}$ of serum and placed in dialysis chambers similar to those described by Averill \& Rowson (1958). The chambers were kept in a water-bath at $30^{\circ}$ to $35^{\circ} \mathrm{C}$ and the eggs remained within the chambers until the time of transfer. The maximum storage time elapsing between recovery and transfer of any egg was $\mathrm{I} h \mathrm{~h}$.

The reproductive tracts of recipient ewes were similarly exposed by laparotomy and transfers were made only to those recipients which had been first observed in oestrus within $24 \mathrm{hr}$ of their respective donors. At the time of transfer, the ovaries were carefully examined and the number of corpora lutea and Graafian follicles of $10 \mathrm{~mm}$ or more in diameter recorded. Potential recipients without at least one corpus luteum were not used.

Eggs containing two to six cells were transferred to the Fallopian tubes, while those containing eight cells or more were placed in the uterine horns. In all recipients, the full complement of eggs to be transferred was placed in either the tubes or uterine horns.

TABLE I

DESIGN OF THE EXPERIMENT

\begin{tabular}{|c|c|c|c|c|c|}
\hline Group & $\begin{array}{l}\text { No. } \\
\text { recipient } \\
\text { ewes }\end{array}$ & Treatment & $\begin{array}{l}\text { No. eggs } \\
\text { transferred } \\
\text { to each } \\
\text { recipient }\end{array}$ & $\begin{array}{l}\text { No. recipient } \\
\text { ewes autopsied on } \\
17 \text { th or } 18 \text { th day } \\
\text { after oestrus }\end{array}$ & $\begin{array}{l}\text { No. ewes } \\
\text { allowed to } \\
\quad \text { lamb }\end{array}$ \\
\hline $\begin{array}{l}\mathrm{N}_{2} \\
\mathrm{~S}_{2} \\
\mathrm{~N}_{5} \\
\mathrm{~S}_{5}\end{array}$ & $\begin{array}{l}20 \\
20 \\
20 \\
20\end{array}$ & $\begin{array}{c}\text { none } \\
\text { super-ovulated } \\
\text { none } \\
\text { super-ovulated }\end{array}$ & $\begin{array}{l}2 \\
2 \\
5 \\
5\end{array}$ & $\begin{array}{l}12 \\
12 \\
12 \\
12\end{array}$ & $\begin{array}{l}8 \\
8 \\
8 \\
8\end{array}$ \\
\hline TOTAI. & 80 & & & $4^{8}$ & 32 \\
\hline
\end{tabular}

Design of the experiment on the effect of superovulation. This is shown in Table I. Of the total of eighty recipient ewes used in this experiment, half, i.e. forty ewes, had been injected with a standard dose of 1500 i.u. PMS on the $13^{\text {th }}$ day of the cycle, immediately preceding the oestrus after which egg transfer was intended. These animals are referred to as superovulated recipients. The remaining forty ewes were left untreated. Each of the two groups of forty ewes was subdivided into two groups, of twenty ewes each, one for the transfer of two eggs $\left(\mathrm{N}_{2}\right.$ and $\left.\mathrm{S}_{2}\right)$ and the other for the transfer of five eggs $\left(\mathrm{N}_{5}\right.$ and $\left.\mathrm{S}_{5}\right)$. In each group of twenty recipients, twelve were examined at autopsy, i.e. on the 17 th or I 8th day after oestrus, while the remaining eight were allowed to go to term. All these twelve recipients destined for autopsy, but only four of those allowed to go to term, received eggs from the Welsh Mountain donors, while the remaining four recipients which were allowed to go to term received eggs from Suffolk donors. Half of the transfers in the case of each breed of eggs were tubal, the other half uterine. 
Autopsy procedures. The reproductive tracts of recipients due for autopsy were removed io to $15 \mathrm{~min}$ after slaughter. The ovaries were removed and the numbers of corpora lutea and large follicles present recorded. The uteri were then opened and any embryos present removed, examined under a binocular microscope and classified as normal or abnormal. The criteria used for classification of embryos were: vascularization of embryo and allantois, heart development and condition of the neural tube. After the classifications had been made, curved crown-rump and length-of-allantois measurements were made on all embryos.

Lambing. Recipients allowed to go to term were kept under constant observation during the last month of pregnancy. As soon after birth as possible, the lambs were earmarked for identification and together with their respective mothers they were separated from those ewes which had not yet lambed.

\section{RESULTS}

A total of 280 fertilized eggs collected from Suffolk and Welsh Mountain donor ewes were transferred at rates of either two or five eggs per animal to the Fallopian tubes or uterine horns of eighty Suffolk recipient ewes. In fortyeight of the recipients, the embryos were examined at autopsy I 7 or 18 days after oestrus. Of these forty-eight animals, thirty-four $(71 \%)$ contained one or more normal embryos (see Table 2). These thirty-four ewes had a total of sixty-six normal embryos representing $39 \%$ of the I 68 eggs transferred to the forty-eight recipients. In thirty-two recipients, the pregnancy was allowed to go to term. Of these thirty-two ewes, twenty-three $(72 \%)$ lambed producing a total of forty-three lambs, representing $38 \%$ of the i 2 eggs transferred to the thirty-two recipients.

\section{FACTORS AFFECTING THE SURVIVAL OF TRANSFERRED EGGS}

\section{Superovulation}

In ewes which had not been treated with PMS, the number of ovulations as assessed by corpora-lutea counts at the time of transfer, some 2 to 4 days after oestrus, varied from one to three with a mean ovulation rate of I. $9 \pm 0.56$. The ovulatory response to the standard dose of 1500 i.u. PMS in the superovulated recipients was somewhat variable. The number of corpora lutea found at the time of transfer varied from two to thirty-eight, with a mean of $9.0 \pm 1.87$. At transfer, many of the ovaries of both the untreated and superovulated recipients contained a number of large unruptured follicles.

It is apparent from Tables 2 and 3 that superovulation had little or no effect upon either the number of ewes which became pregnant or on the survival of transferred eggs. Of the fifty-seven ewes which became pregnant (thirty-four examined at autopsy, i.e. on the I 7 th or 18 th day after oestrus, and twentythree at term), thirty were untreated and twenty-seven were superovulated $\left(x^{2}=0.549 ; P>0.30\right)$. Similarly, in ewes receiving the same number of eggs, superovulation seemed to have had no significant effect upon the proportion of transferred eggs which developed into normal embryos or lambs. 
Table 4 shows the numbers of corpora lutea and large follicles at transfer and slaughter in the thirty-four ewes found pregnant at autopsy. These ewes had at the time of transfer a total of 196 corpora lutea and 44 large follicles, whereas the same ewes at slaughter had 218 corpora lutea and no large follicles.

TABLE 2

SURVIVAL AND DEVELOPMENT OF TRANSFERRED EGGS AS ASSESSED AT AUTOPSY ON I7TH OR I 8TH DAYS AFTER OESTRUS

\begin{tabular}{|c|c|c|c|c|c|c|}
\hline \multirow{2}{*}{ Group } & \multirow{2}{*}{$\begin{array}{l}\text { Total } \\
\text { ewes }\end{array}$} & \multirow{2}{*}{$\begin{array}{l}\text { Total eggs } \\
\text { transferred }\end{array}$} & \multicolumn{2}{|c|}{ Embryos } & \multirow{2}{*}{$\begin{array}{l}\text { Normal embryos } \\
\text { per pregnant ewe }\end{array}$} & \multirow{2}{*}{ Eggs lost } \\
\hline & & & Normal & Abnormal & & \\
\hline $\begin{array}{l}\mathrm{N}_{2} \\
\mathrm{~S}_{2} \\
\mathrm{~N}_{5} \\
\mathrm{~S}_{5}\end{array}$ & $\begin{array}{l}12 \\
12 \\
12 \\
12\end{array}$ & $\begin{array}{l}24 \\
24 \\
60 \\
60\end{array}$ & $\begin{array}{l}\text { I6 }(67 \%) \\
\text { I2 }(50 \%) \\
20(33 \%) \\
\text { I8 }(30 \%)\end{array}$ & $\begin{array}{l}2 \\
3 \\
9 \\
7\end{array}$ & $\begin{array}{l}1.6 \\
1.5 \\
2.5 \\
2.3\end{array}$ & $\begin{array}{r}6(25 \%) \\
9(37 \%) \\
31(52 \%) \\
35(58 \%)\end{array}$ \\
\hline TOTAL & 48 & 168 & $66(39 \%)$ & 21 & 1.9 & $81(48 \%)$ \\
\hline
\end{tabular}

TABLE 3

SURVIVAL AND DEVELOPMENT OF TRANSFERRED EGGS AS ASSESSED BY NUMBERS OF LAMBS BORN

\begin{tabular}{|c|c|c|c|c|c|c|}
\hline \multirow{2}{*}{ Group } & \multirow{2}{*}{$\begin{array}{l}\text { Total } \\
\text { ewes }\end{array}$} & \multirow{2}{*}{$\begin{array}{l}\text { Total eggs } \\
\text { transferred }\end{array}$} & \multirow{2}{*}{$\begin{array}{c}\text { Ewes } \\
\text { lambing }\end{array}$} & \multicolumn{2}{|c|}{ No. lambs } & \multirow{2}{*}{$\begin{array}{c}\text { Prenatal loss } \\
\text { of eggs }\end{array}$} \\
\hline & & & & Total & $\begin{array}{l}\text { Per ewe } \\
\text { lambing }\end{array}$ & \\
\hline $\begin{array}{l}N_{2} \\
\mathrm{~S}_{2} \\
\mathrm{~N}_{5} \\
\mathrm{~S}_{5}\end{array}$ & $\begin{array}{l}8 \\
8 \\
8 \\
8\end{array}$ & $\begin{array}{l}16 \\
16 \\
40 \\
40\end{array}$ & $\begin{array}{l}7 \\
5 \\
5 \\
6\end{array}$ & $\begin{array}{r}10(62 \%) \\
8(50 \%) \\
10(25 \%) \\
15(37 \%)\end{array}$ & $\begin{array}{l}1.4 \\
1.3 \\
2.0 \\
2.5\end{array}$ & $\begin{array}{r}6(38 \%) \\
8(50 \%) \\
30(75 \%) \\
25(63 \%)\end{array}$ \\
\hline TOTAL & $3^{2}$ & 112 & 23 & $43(38 \%)$ & 1.9 & $69(62 \%)$ \\
\hline
\end{tabular}

TABLE 4

NUMBERS OF CORPORA LUTEA AND LARGE FOLLICLES AT TRANSFER AND AT AUTOPSY IN REGIPIENT EWES WHICH BECAME PREGNANT

\begin{tabular}{|c|c|c|c|c|c|}
\hline \multirow[b]{2}{*}{ Treatment } & \multicolumn{2}{|c|}{ No. corpora lutea } & \multicolumn{2}{|c|}{ No. large follicles } & \multirow{2}{*}{$\begin{array}{c}\text { Increase } \\
\text { in No. } \\
\text { corpora } \\
\text { lutea }\end{array}$} \\
\hline & At transfer & At autopsy & At transfer & At autopsy & \\
\hline $\begin{array}{l}\text { None } \\
\text { Superovulated }\end{array}$ & $\begin{array}{r}37 \\
159\end{array}$ & $\begin{array}{r}40 \\
178\end{array}$ & $\begin{array}{r}5 \\
39\end{array}$ & $\begin{array}{l}\circ \\
\circ\end{array}$ & $\begin{array}{r}3 \\
19\end{array}$ \\
\hline TOTAL & 196 & $2 \times 8$ & 44 & 0 & 22 \\
\hline
\end{tabular}

Between the times of transfer and autopsy, the number of corpora lutea had therefore increased by twenty-two ( I I \%). The increase occurred in only those ewes which contained at the time of transfer unruptured large follicles and in no ewe did the increase in the number of corpora lutea exceed the number of large follicles found at transfer. Both the untreated and superovulated ewes 
showed this phenomenon and at autopsy the extra corpora lutea could not be distinguished by macroscopic means from those which were present at the time of transfer.

\section{Number of eggs transferred}

Since superovulation had no significant effect upon either the number of ewes becoming pregnant or on the survival of eggs, it was decided to pool the data obtained from superovulated and non-treated recipients and to examine them jointly (Tables 5 and 6 ). It is apparent from Tables 5 and 6 that the number of eggs transferred had no significant effect upon the number of ewes which

TABLE 5

POOLED DATA FOR SUPEROVULATED AND UNTREATED RECIPIENTS: AT AUTOPSY

\begin{tabular}{|c|c|c|c|c|c|c|}
\hline \multirow{2}{*}{$\begin{array}{c}\text { No. eggs } \\
\text { transferred } \\
\text { to each } \\
\text { recipient }\end{array}$} & \multirow{2}{*}{$\underset{\text { recipients }}{\text { No. }}$} & \multirow{2}{*}{$\begin{array}{l}\text { No. ewes } \\
\text { pregnant }\end{array}$} & \multicolumn{2}{|c|}{ Embryos recovered } & \multirow{2}{*}{$\begin{array}{c}\text { Normal } \\
\text { embryos per } \\
\text { pregnant ewe }\end{array}$} & \multirow{2}{*}{ Eggs lost } \\
\hline & & & Normal & Abnormal & & \\
\hline $\begin{array}{l}2 \\
5\end{array}$ & $\begin{array}{l}24 \\
24\end{array}$ & $\begin{array}{l}18 \\
16\end{array}$ & $\begin{array}{l}28(58 \%) \\
38(32 \%)\end{array}$ & $\begin{array}{r}5(10 \%) \\
16(13 \%)\end{array}$ & $\begin{array}{l}a_{1.6} \\
b_{2.4}\end{array}$ & $\begin{array}{l}15(32 \%) \\
66(55 \%)\end{array}$ \\
\hline TOTAL & 48 & 34 & $66(39 \%)$ & $21(13 \%)$ & 1.9 & 8 I $(48 \%)$ \\
\hline
\end{tabular}

Comparison of mean numbers of normal embryos carried at autopsy between ewes receiving two and five eggs.

a $v$ b: $\mathrm{t}=2.93 ; P<0.01$.

TABLE 6

POOLED DATA FOR SUPEROVULATED AND UNTREATED REGIPIENTS: AT TERM

\begin{tabular}{c|c|c|c|c|c}
\hline $\begin{array}{c}\text { No. eggs } \\
\text { transferred } \\
\text { to each } \\
\text { recipient }\end{array}$ & $\begin{array}{c}\text { No. } \\
\text { recipients }\end{array}$ & $\begin{array}{c}\text { No. ewes } \\
\text { pregnant }\end{array}$ & $\begin{array}{c}\text { Lambs } \\
\text { born }\end{array}$ & $\begin{array}{c}\text { Total pre- } \\
\text { natal loss } \\
\text { of eggs }\end{array}$ & $\begin{array}{c}\text { Lambs born } \\
\text { per ewe } \\
\text { lambing }\end{array}$ \\
\hline 2 & 16 & 12 & $18(56 \%)$ & $14(44 \%)$ & ${ }^{c_{1.5}}$ \\
\hline 5 & 16 & 11 & $25(31 \%)$ & $55(69 \%)$ & $\mathrm{d}_{2.3}$ \\
\hline TOTAL & 32 & 23 & $43(38 \%)$ & $69(62 \%)$ & 1.9 \\
\hline
\end{tabular}

Comparison of mean numbers of lambs born at term between ewes receiving two and five eggs.

c $v \mathrm{~d}: \mathrm{t}=2.90 ; P<0.01$.

subsequently became pregnant. However, those ewes which received five eggs and subsequently became pregnant averaged more normal embryos at autopsy and lambs at term than those receiving two eggs.

Site of transfer

In each group of ewes, half the transfers were made into the Fallopian tubes, the other half into the uterus. Tables 7 and 8 show the results obtained by the tubal and uterine transfers.

The results at autopsy and at term conform to the same pattern. A greater number, not significantly so, however, of ewes in which transfers were made 
to the uterine horns were pregnant at autopsy or subsequently lambed than of those ewes in which the transfers were tubal.

The greater success following uterine transfers was more conclusively shown by the proportion of eggs which developed into normal embryos and lambs. In those ewes destined for autopsy, the difference was found to be significant whereas in the term ewes the difference only approached the $5 \%$ level. The increased survival rate was further shown by the mean numbers of normal embryos per pregnant ewe at autopsy and the mean numbers of lambs born per ewe lambing at term.

\section{TABLE 7}

EGG SURVIVAL IN RELATION TO THE SITE OF TRANSFER: AT AUTOPSY

\begin{tabular}{|c|c|c|c|c|c|c|}
\hline \multirow{2}{*}{$\begin{array}{l}\text { No. eggs } \\
\text { transferred } \\
\text { to each } \\
\text { recipient }\end{array}$} & \multicolumn{2}{|c|}{ No. ewes pregnant } & \multicolumn{2}{|c|}{ No. normal embryos } & \multicolumn{2}{|c|}{$\begin{array}{l}\text { Mean No. normal embryos } \\
\text { per pregnant ewe }\end{array}$} \\
\hline & Tubal & Uterine & Tubal & Uterine & Tubal & Uterine \\
\hline $\begin{array}{l}2 \\
5\end{array}$ & $\begin{array}{l}8 \\
7\end{array}$ & $\begin{array}{r}\text { Io } \\
9\end{array}$ & $\begin{array}{l}\text { II } \\
\text { I3 }\end{array}$ & $\begin{array}{l}17 \\
25\end{array}$ & $\begin{array}{l}1.4 \\
1.9\end{array}$ & $\begin{array}{l}1.7 \\
2.8\end{array}$ \\
\hline TOTAL & $a_{15}$ & $b_{19}$ & $e_{24}$ & $t_{42}$ & 1.6 & 2.2 \\
\hline
\end{tabular}

Comparisons between tubal and uterine transfers:

Ewes pregnant at autopsy: $\mathrm{a} v \mathrm{~b} ; \mathrm{x}^{2}=1.613 ; P>0.20$.

Normal embryos at autopsy; e $v$ f; $x^{2}=8.086 ; P<0.01$.

TABLE 8

EGG SURVIVAL IN RELATION TO THE SITE OF TRANSFER: AT TERM

\begin{tabular}{c|c|c|c|c|c|c}
\hline $\begin{array}{c}\text { No. eggs } \\
\text { transferred } \\
\text { to each } \\
\text { recipient }\end{array}$ & No. ewes lambing & \multicolumn{2}{|c|}{ No. lambs born } & \multicolumn{2}{c}{$\begin{array}{c}\text { Mean No. lambs } \\
\text { per ewe lambing }\end{array}$} \\
\cline { 2 - 6 } & Tubal & Uterine & Tubal & Uterine & Tubal & Uterine \\
\hline 2 & 6 & 6 & 8 & 10 & 1.3 & 1.7 \\
5 & 4 & 7 & 9 & 16 & 2.3 & 2.3 \\
\hline Total & $\mathrm{c}_{10}$ & $\mathrm{~d}_{13}$ & $\mathrm{~g}_{17}$ & $\mathrm{n}_{26}$ & 1.7 & 2.0 \\
\hline
\end{tabular}

Comparisons between tubal and uterine transfers:

Ewes lambing at term: $c y d ; x^{2}=1.391 ; P>0.20$.

Lambs born at term: $\mathrm{g} v \mathrm{~h} ; \mathrm{X}^{2}=3.05^{8}$; $0.10<P>0.05$.

Breed of eggs used for transfer

The breed origin of egg transferred had no significant effect upon either the proportion of ewes which subsequently became pregnant or on egg survival. Welsh eggs survived equally well as Suffolk eggs when transferred to the Suffolk recipients.

\section{PRENATAL LOSS OF TRANSFERRED EGGS}

Recipients due for autopsy provided information on the losses occurring up to I 7 or 18 days after oestrus, whilst the 'term-animals' gave a measure of the total losses occurring during the whole pregnancy. Losses which took place up 
to the time of autopsy were considered to represent embryonic death and those occurring after the $17^{\text {th }}$ or 18 th day, foetal death. Foetal mortality, therefore, can be expressed as the difference between the number of eggs which survived to term and those which survived only to the I 7 th or 18 th day after oestrus.

Embryos classified as abnormal were considered to be non-viable. Of the twenty-one abnormal embryos recovered at autopsy (see Table 5), three were resorbing and eighteen were retarded in development in relation to normal embryos of similar age. Green \& Winters (1945) found that the neural tubes at just under 16 days were enclosed to the region of the hind gut. In twelve of

TABLE 9

SIZE OF EMBRYOS RECOVERED FROM AUTOPSIED RECIPIENTS. MEAN GROWN-RUMP AND LENGTH-OF-ALLANTOIS MEASUREMENTS

\begin{tabular}{|c|c|c|c|c|c|c|}
\hline \multirow{3}{*}{ Group } & \multirow{2}{*}{\multicolumn{2}{|c|}{ No. embryos recovered }} & \multicolumn{4}{|c|}{ Mean embryo measurements } \\
\hline & & & \multicolumn{2}{|c|}{ Normal } & \multicolumn{2}{|c|}{ Abnormal } \\
\hline & Normal & Abnormal & Crown-rump & Allantois & Crown-rump & Allantois \\
\hline $\begin{array}{l}\mathrm{N}_{2} \\
\mathrm{~S}_{2} \\
\mathrm{~N}_{5} \\
\mathrm{~S}_{5}\end{array}$ & $\begin{array}{l}16 \\
12 \\
20 \\
18\end{array}$ & $\begin{array}{l}2 \\
3 \\
9 \\
7\end{array}$ & $\begin{array}{l}6.6 \\
6.8 \\
6.6 \\
6.6\end{array}$ & $\begin{array}{r}8.6 \\
10.2 \\
9.4 \\
9.0\end{array}$ & $\begin{array}{l}3.0 \\
3.0 \\
3.4 \\
3.9\end{array}$ & $\begin{array}{l}3.3 \\
0.6 \\
1.9 \\
2.4\end{array}$ \\
\hline TOTAL & 66 & $2 \mathrm{I}$ & ${ }^{a} 6.6$ & ${ }^{c} 9.2$ & $b_{3.5}$ & $\mathrm{~d}_{2.0}$ \\
\hline
\end{tabular}

All measurements in $\mathrm{mm}$.

Comparison of mean measurements of normal and abnormal embryos:

Crown-rump: a $v$ b; $\mathrm{t}=16.84 ; P<0.001$.

Allantois length: $\mathrm{c} v \mathrm{~d} ; \mathrm{t}=6.82 ; P<0.001$.

TABLE IO

RELATIONSHIP BETWEEN THE MEAN SIZE OF EMBRYOS AND THE LITTER SIZE

\begin{tabular}{c|c|c|c}
\hline \multirow{2}{*}{$\begin{array}{c}\text { Litter } \\
\text { size }\end{array}$} & $\begin{array}{c}\text { Total No. } \\
\text { embryos }\end{array}$ & \multicolumn{2}{|c}{ Mean measurements $(\mathrm{mm})$} \\
\cline { 3 - 4 } & & Crown-rump & Allantois \\
\hline $\mathrm{I}$ & $\mathrm{I} 2$ & 6.5 & 9.0 \\
2 & 30 & 6.6 & 8.9 \\
3 & 12 & 6.5 & 8.9 \\
4 & 12 & 6.8 & 10.7 \\
\hline
\end{tabular}

the eighteen retarded embryos, the neural tubes had failed to close, whilst in the remaining six the neural tubes had closed but they all showed only very limited vascularization of both the embryo and the allantois.

Measurements, taken after classification, showed a further difference between normal and abnormal embryos. All embryos considered as normal had a crown-rump measurement of $5 \mathrm{~mm}$ or more, whilst all abnormals were less than $5 \mathrm{~mm}$. The mean length of the allantois in normal embryos was significantly greater than in the abnormal ones (see Table 9). As can be seen from Table so neither superovulation of the recipients nor the number of eggs transferred seemed to have any great effect upon the size of the resulting embryos. 
The sixty-six normal embryos recovered at autopsy, i.e. on the 17 th or 18 th day after oestrus, were made up of twelve carried as singles, thirty as twins, twelve as triplets and twelve as quadruplets (Table Io). However, no significant difference could be found between either the mean crown-rump length or the mean length of allantois of individual embryos carried as singles, twins, triplets and quadruplets.

Two peaks of embryonic mortality were observed, one occurring very early in pregnancy and recorded as egg loss and the other occurring a little later and represented by abnormal embryos. Embryonic mortality accounted for I02 $(6 \mathrm{I} \%)$ of the total number of eggs transferred. Eighty-one perished before attachment, the remaining twenty-one after attachment. In fourteen of the forty-eight recipients destined for autopsy, pregnancy was terminated by embryonic mortality. Twelve of these ewes lost all their eggs before attachment

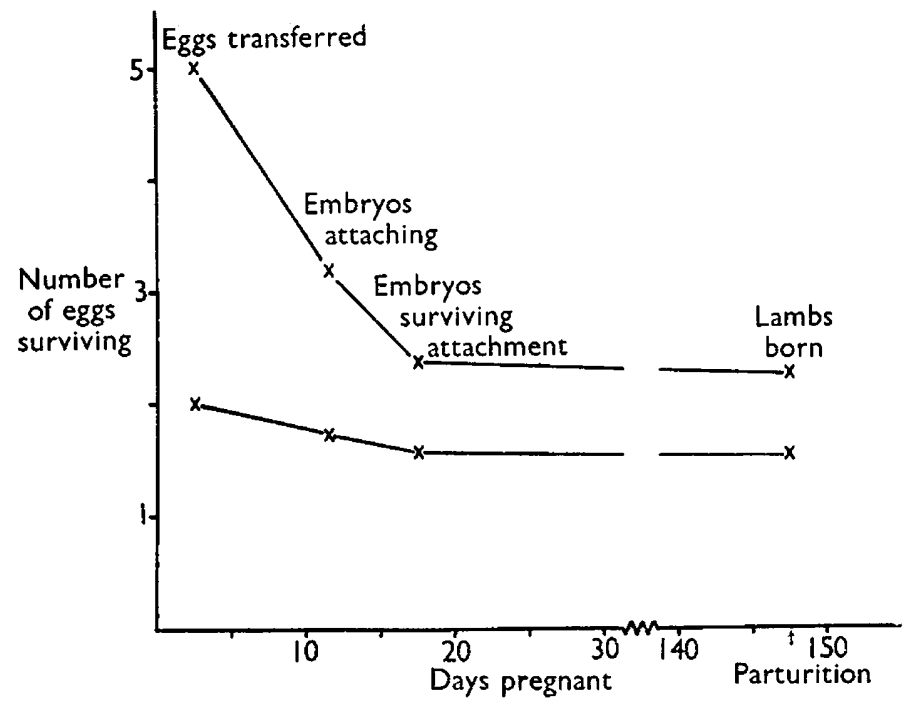

TEXT-FIG. I. Survival of transferred eggs.

and showed no embryonic remains at all at autopsy. Of the remaining two ewes, one lost the two eggs transferred to her after attachment, i.e. she had two abnormal embryos at autopsy, whilst the other ewe which received five eggs lost two before attachment and had three abnormal embryos.

Thirty-eight per cent of the eggs transferred to the term recipients developed into lambs, whereas $39 \%$ of the eggs transferred to the autopsy recipients were represented by normal embryos. This would suggest that probably very little foetal loss occurred between $\mathrm{I} 7$ or 18 days and term.

Analysis of prenatal loss

Tables 5 and 6 and Text-fig. I show the survival of eggs transferred at rates of two and five eggs per recipient. Although those ewes which received five eggs had significantly more normal embryos at autopsy and lambs at term, the proportion of transferred eggs which survived to normal embryos and lambs 
following the transfer of five eggs was significantly less than in the other group of recipients which received only two eggs. The respective survival rates following two- and five-egg transfers were at autopsy 58 and $32 \%\left(\chi^{2}=10.222\right.$; $P<0.01)$ and at term 56 and $31 \%\left(X^{2}=6.040 ; P<0.02\right)$. The higher embryonic loss observed in those ewes which received five eggs was due mainly to an increased and significantly greater pre-attachment loss. In the autopsied recipients, $55 \%$ of the eggs transferred at the rate of five per recipient died before attachment whereas only $32 \%$ of those transferred at the rate of two per recipient perished at the same stage of pregnancy $\left(X^{2}=7.745 ; P<0.01\right)$. The proportions of transferred eggs lost after attachment following the transfer of two and five eggs were respectively io and $13 \%\left(\chi^{2}=0.267 ; P>0.50\right)$, while foetal losses ( 17 or 18 days to term) were $2 \%$ and I $\%$, respectively.

TABle II

THE RELATIONSHIP BETWEEN LITTER SIZE AND POST-ATTAGHMENT EMBRYONIC LOSS

\begin{tabular}{c|c|c|c|c|c}
\hline \multirow{2}{*}{ Litter size } & \multirow{2}{*}{ No. litters } & \multicolumn{2}{|c|}{$\begin{array}{c}\text { Litters showing } \\
\text { post-attachment loss }\end{array}$} & \multicolumn{2}{|c}{$\begin{array}{c}\text { Embryos dying after } \\
\text { attachment }\end{array}$} \\
\cline { 3 - 6 } & & No. & $\%$ & No. & $\%$ \\
\hline I & 7 & 0 & 0 & 0 & 0 \\
2 & 18 & 6 & 33 & 7 & 19 \\
3 to 5 & 1 & 8 & 73 & 14 & 32 \\
\hline
\end{tabular}

This would suggest that mortality occurring after attachment was not greatly influenced by the number of eggs transferred. However, post-attachment mortality can be expressed as the proportion of the attached embryos which perished. Following the transfer of two and five eggs, thirty-three and fifty-four embryos, respectively, became attached and five (15\%) and sixteen $(30 \%)$, respectively, perished after attachment. This difference in mortality rates of attached embryos, although not significant $\left(\chi^{2}=2.344 ; P>0.05\right)$, suggests that post-attachment embryonic mortality may have been influenced by the numbers of embryos becoming attached. The increased post-attachment mortality which occurred in recipients with larger numbers of embryos attaching is further shown in Table I I.

Embryonic mortality appeared to reduce the number of embryos to a number which the ewes were capable of carrying to term. Those ewes which received two eggs produced an average of $\mathrm{I} .5$ lambs each. The corresponding figures for five-egg transfers were 2.4 per ewe lambing. The severe reduction in embryo numbers, especially following the transfer of five eggs and the subsequent survival and development of most embryos surviving attachment is illustrated in Text-fig. I. From the data obtained at term and autopsy, the distribution of the total prenatal loss can be calculated. In ewes receiving five eggs, $80 \%$ of the total loss occurred before attachment, $19 \%$ postattachment whilst only $\mathrm{r} \%$ was foetal loss. The corresponding figures for ewes receiving two eggs was $73 \%$ pre-attachment, $23 \%$ post-attachment and $4 \%$ foetal loss. 


\section{DISGUSSION}

Classification of embryos

Embryos recovered at autopsy, i.e. on I 7 th or i 8 th day after oestrus, were classified on the basis of their appearance. Those found resorbing were obviously dead, but the 'retarded' ones did present some problem as to their viability. With the criteria used for classification, it was very difficult to determine whether these retarded embryos were in fact alive or dead at the time of autopsy. Robinson (195I) experienced similar difficulties with embryos recovered from ewes which were up to 3 weeks pregnant. He considered that retarded embryos were in fact non-viable and that retardation represents the beginning of embryonic death. The observation that the number of lambs born per ewe in the group of recipients allowed to go to term was almost identical with the number of normal embryos carried by a pregnant ewe at autopsy provides strong evidence that the retarded embryos were in fact non-viable.

Autopsies carried out a few days later than the 17 th or 18 th day after oestrus could possibly provide more direct evidence concerning the viability of retarded embryos. However, resorption of embryos in the ewe is extremely rapid and if autopsies were carried out later than the 2 ist day of pregnancy then the resorbing embryos, and perhaps many of those 'retarded' at the I 7 th or 18 th day, would have resorbed to such an extent as to be unrecognizable. In some other species, notably the rabbit, the problem of recognizing dead embryos is not as acute as in the ewe. Prenatal mortality in the rabbit has been studied in some detail by Allen, Brambell \& Mills (1947), Brambell \& Mills (1948), Brambell, Henderson \& Mills (1948) and Adams (1959). All these authors found that implantation sites of dead embryos, even those dying very soon after implantation, persist to term. Implantation in the rabbit occurs about the 7 th day after mating and a newly implanted rabbit embryo is at a stage of development similar to a 17 th- or I 8 th-day sheep embryo.

If retarded sheep embryos are in fact non-viable, and the evidence available strongly suggests that this is the case, then embryos at $\mathrm{I} 7$ or 18 days might be classified as to their viability by simply taking crown-rump measurements. All those measuring more than $5 \mathrm{~mm}$ would be classified as viable and those of less than $5 \mathrm{~mm}$ non-viable. The use of measurements for the purpose of discriminating between viable and non-viable embryos has been demonstrated in other species. Adams (1959) found that ro-days-old rabbit embryos giving uterine swelling diameters of $11.5 \mathrm{~mm}$ or less were not viable, whereas the majority of those with a diameter of $12 \mathrm{~mm}$ or more survived to term.

\section{Prenatal mortality}

Prenatal losses fall into three main categories, namely fertilization failure, embryonic mortality and foetal mortality. Our experiments were specifically designed to investigate embryonic and foetal mortality. Fertilization failure played no part in prenatal loss as only fertilized eggs were transferred.

\section{Embryonic mortality}

It was apparent from the autopsied ewe recipients that two peaks of embryonic mortality occurred. These were called pre- and post-attachment 
mortality, respectively. Embryos dying before attachment left no remains at all at 17 or I 8 days, whilst those which succumbed after attachment were represented by abnormal embryos. Both Robinson (I95I) and Averill (I956) reported similar findings. Averill referred to the two peaks as pre- and postimplantation losses, whilst Robinson called them pre- and post-attachment losses. Green \& Winters (1945) claimed that the sheep blastocyst first attaches itself to the endometrium on about the Ioth day after mating, but implantation, which in the ewe is a lengthy procedure, is not complete until probably about the $4^{\text {th }}$ to $5^{\text {th }}$ week after oestrus, when there is a firm attachment between the foetal membranes and the maternal cotyledons (Amoroso, I952).

The time at which pre-attachment mortality took place was rather difficult to assess, but it would seem that it occurred some time before the $14^{\text {th }}$ or $15^{\text {th }}$ day after oestrus. The stage of development reached by the embryo and its membranes at 14 to 15 days is such that any embryo dying at this time in all probability leaves some identifiable remains at autopsy. The same difficulties were not experienced in determining the stage of pregnancy at which postattachment loss occurred. The stage of development reached by the retarded embryos was very similar to the 14- to 15 -day sheep embryos illustrated by Green \& Winters (1945). Whether these embryos were just three or four days retarded in relation to the normal embryos or whether they had died cannot be clearly stated.

Forty-four and $69 \%$, respectively, of eggs transferred to term-recipients at the rates of two and five eggs per ewe, were not represented by lambs at term. The autopsy results indicated that almost all the loss was embryonic and that much of the increased embryonic mortality following the transfer of five eggs was due to an increased pre-attachment embryonic loss. In fact, in both groups pre-attachment death accounted for the majority of prenatal loss. Hammond (1921) and Henning (1939) found from slaughter studies on pregnant ewes that prenatal mortality increased as the number of eggs shed increased. Henning reported that 8,26 and $43 \%$, respectively, of eggs shed by ewes with one, two and three corpora lutea were either missing or represented by dead foetuses. These figures were obtained from pregnant animals only, most of which were slaughtered late in pregnancy.

Brambell (1948) from an analysis of the data presented by Henning calculated that the total prenatal loss in a flock of ewes similar to those of Henning would be of the order of $40 \%$ of the eggs shed. He further suggested that this loss would be distributed at random between ewes with one, two and three ovulations. However, these results and those of Robinson (195I) show fairly conclusively that the proportion of eggs suffering prenatal mortality does increase quite markedly as the number of eggs shed or transferred increases.

\section{Causes of prenatal mortality}

Brambell (1948), from extensive studies on the wild rabbit, suggested that prenatal mortality may result from either maternal or foetal failure. Maternal failure would tend to fall on the litters as a whole, resulting in a complete loss of the pregnancy, while foetal failure would tend to fall on the individual foetuses or embryos, resulting in partial loss of the pregnancy. Brambell also 
postulated a third type of mortality due to intermediate factors where the probability of loss in some litters was greater than in others. He quoted as examples the cases where the maternal environment may be unfavourable and is such that not all of the embryos present can be supported, or where there are greater possibilities for the inheritance of lethals.

In 28 and $29 \%$, respectively, of the autopsy and term recipients all the transferred eggs were lost and in these animals maternal factors were probably operating. Most of the loss in these recipients as illustrated by the autopsy results occurred before attachment. In those recipients which became pregnant to egg transfer but had less embryos at autopsy and lambs at term than the number of eggs transferred, prenatal loss was due to either embryonic failure or intermediate factors. These experiments do not provide direct evidence on which of the two factors was operating, but Robinson (195I) argued that the intermediate factors were the most important. He suggested that the uterine environment was in some way lacking and could only support a limited number of embryos.

Hammond (I92I and I952), Brambell (I948) and Robinson (I95I) all suggested that embryonic loss might be due to some deficiency, perhaps nutritional, of the uterine environment. Hammond (1952) went as far as to propose the presence of a specific substance. He suggested that the number of embryos which survive might be dependent upon the amount of this substance present. If overall nutrition were important, then it might be expected that embryos carried as multiples would tend to be smaller than those present as singles. However, no significant difference could be found between the size of embryos carried as singles, twins, triplets and quadruplets.

\section{Foetal mortality}

In recipients which received the same number of eggs, the average number of normal embryos carried per pregnant ewe at autopsy was very similar to the average number of lambs produced per ewe lambing. It would seem then that very little mortality occurred after I 7 or 18 days, although it might be argued that a number of the embryos found retarded at autopsy might be capable of some further development but would die during foetal life.

\section{FACTORS AFFEGTING THE SURVIVAL AND DEVELOPMENT OF TRANSFERRED EGGS}

\section{Site of transfer}

The uterine horns were found to be a more successful site for transferred eggs than the Fallopian tubes. Not only did more ewes become pregnant following uterine transfers but these recipients had more normal embryos and lambs than those in which transfers were made into the tubes. Similar observations were made by Averill (1956) who found that $83 \%$ of 6 - to 16-cell eggs transferred to the uterine horns and only $40 \%$ of 2 - and 4 -cell eggs transferred to the tubes developed into lambs.

The reasons for the lower survival rates following tubal transfers are obscure but two explanations could be advanced. Firstly, sheep eggs at the early cleavage stages may be particularly susceptible to death resulting from storage 
and transfer and, secondly, accelerated and retarded tubal transport may occur following tubal transfers. There seems to be little evidence to support the first explanation, since Chang ( $1947,1948 \mathrm{a}, \mathrm{b}, 1950$ ) found that fertilized rabbit eggs from the uncleaved state to 6-day blastocysts were all capable of surviving storage in rabbit serum for $24 \mathrm{hr}$, with some indication that 2-cell eggs survived storage better than the more advanced stages. The second alternative provided a more likely explanation. If the tubal transport which follows tubal transfers is either too rapid or too slow, some of the eggs may reach the uterus at the physiologically incorrect time. Averill \& Rowson (1958) reported that no 2-cell egg and only $16 \%$ of the 4 -cell sheep eggs developed into lambs when transferred to the uterine horns. Similarly, Fekete \& Little (1942) found that no 2-cell mouse eggs survived when transferred to the uterine horns.

It has been demonstrated by Robinson (195I) in the ewe and by Dowling (1949) in the cow that superovulation may result in a rapid tubal transport and it might therefore be expected that tubal transfers to superovulated recipients are less successful than those to untreated ewes. However, in our study this was not the case, survival rates following tubal transfers being equally poor for both superovulated and untreated recipients. This problem needs further investigation. Autopsies, for the purpose of egg recovery, performed only a few hours after the time of transfer could possibly provide information on the movement of eggs following tubal transfer.

\section{Number of eggs transferred}

The transfer of five eggs instead of two to each recipient did not increase the proportion of ewes which became pregnant. It would seem then that the success or failure of any transfer was dependent more on the inherent ability of the ewe to support a pregnancy than on the number of eggs transferred.

Altogether $72 \%$ of the recipients had either normal embryos at autopsy or lambs at term. This figure is in close agreement with the figure of 70 to $80 \%$ of ewes conceiving to service at a single oestrous period (Quinlan \& Mare, 1931; Darlow \& Hawkins, 1932; Underwood \& Shier, I94I; and others). It seems that quite a high proportion of ewes, namely 20 to $30 \%$, is incapable of becoming pregnant at any one oestrous period, but failure to become pregnant at this single oestrus does not necessarily indicate the presence of any permanent factors affecting fertility. In our study, for example, some of the recipients destined to go to term were found to be non-pregnant, yet the same animals conceived later either to natural service or to a second egg transfer. It would seem then that a number of ewes at any oestrous period are suffering from some form of transient infertility which may well be of endocrine origin. It is unlikely that fertilization failure can be responsible for the fact that 20 to $30 \%$ of ewes do not conceive to natural service. Fertilization has been observed in $90 \%$ or more of eggs shed (Robinson, 195 I ; Averill, 1956). It has been found that $97 \%$ of well over 500 sheep eggs collected for transfer showed normal cleavage (N. W. M. - unpublished data). Similar observations have been made in cattle following artificial insemination (Walton, 1958). Even when bulls with the best quality semen are used for insemination, conception rates of over $75 \%$ are extremely rare. Laing (1949) and Tanabe \& Casida (1949) have 
presented evidence that the early death of fertilized eggs, and not fertilization failure, accounts for the failure of the majority of cows to conceive after insemination.

\section{ACKNOWLEDGMENTS}

This investigation was carried out on behalf of the Agricultural Research Council. One of the authors (N. W. M.) wishes to acknowledge gratefully the receipt of a Science and Industry Fund Overseas Studentship administered by the Commonwealth Scientific and Industrial Research Organization of Australia.

We are indebted to $\mathrm{Dr} \mathrm{T}$. Mann, F.R.s., for reading and discussing the manuscript, to Mr G. Pluck for the care of experimental animals, to Mr Strange for his invaluable assistance and to Messrs Boots Pure Drug Co for the assay of PMS.

\section{REFERENCES}

AdAms, C. E. (1959) Studies on prenatal mortality in the rabbit, Oryctolagus cuniculus: the amount and distribution of loss before and after implantation. 7. Endocrin. 19, 325 .

Allen, P., Brambell, F. W. R. \& Mills, I. H. (1947) Studies on sterility and prenatal mortality in wild rabbits. I. The reliability of estimates of prenatal mortality based on counts of corpora lutea, implantation sites and embryos. 7. $\exp$. Biol. 23, 312.

Amoroso, C. E. (I952) Placentation. Marshall's Physiology of Reproduction, 3rd edn, vol. 2, p. 193. Ed. A. S. Parkes. Longmans, Green \& Co, London.

Averill, R. L. W. (1956) Studies in the fertility of the ewe. Thesis, University of Cambridge.

Averill, R. L. W. (1958) Production of viable sheep eggs. 7. agric. Sci. 50, I 7.

Averill, R. L. W. \& Rowson, L. E. A. (1958) Ovum transfer in the sheep. 7 . Endocrin. 16, 326.

Brambell, F. W. R. (1948) Prenatal mortality in mammals. Biol. Rev. 23, 370.

Brambell, F. W. R., Henderson, M. \& Mills, I. H. (1948) The experimental induction of prenatal mortality and subsequent elimination of the dead embryos in rabbits. 7. exp. Biol. 25, 209.

Brambell, F. W. R. \& Mills, I. H. ( 1948 ) Studies on sterility and prenatal mortality in wild rabbits. Part IV. The loss of embryos after implantation. 7. exp. Biol. 25, 241.

Casida, L. E., Warwick, E. J. \& Meyer, R. K. (I944) Survival of multiple pregnancy in the ewe following treatment with pituitary gonadotrophins. 7. Anim. Sci. 3, 22.

Chang, M. C. (1947) Normal development of fertilized rabbit ova stored at low temperatures for several days. Nature, Lond. $159,602$.

Chang, M. C. (1948a) Transplantation of fertilized rabbit ova; the effect on viability of age, in vitro storage period and storage temperature. Nature, Lond. 161, 978.

Chang, M. C. (1948b) The effects of low temperature on fertilized rabbit ova in vitro and the normal development of ova kept at low temperatures for several days. 7 . gen. Physiol. 31,385 .

Chang, M. C. (I950) Development and fate of transferred rabbit ova and blastocysts in relation to the ovulation time of the recipients. 7. exp. Zool. 114, 197.

Dariow, A. E. \& Hawkins, L. E. (I932) The influence of nutrition on the oestrous cycle of the ewe. Rec. Amer. Soc. Anim. Prod., p. 173.

Dowling, D. F. (1949) Problems of transplantation of fertilized ova. F. agric. Sci. 39, 374.

Fekete, E. \& LitTle, C. C. (1942) Observations on the mammary tumour incidence of mice born from transferred ova. Cancer Res. 2, 525.

Green, W. W. \& Winters, L. M. (1945) Prenatal development in the sheep. Tech. Bull. Minn. agric. Exp. Sta., No. 169 .

HAMmond, J. (1921) Further observations on the factors controlling fertility and foetal atrophy. 7. agric. Sci. I1, 337 .

Hammond, J. (1952) Fertility. Marshall's Physiology of Reproduction, 3rd edn, vol. 2, p. 706. Ed. A. S. Parkes. Longmans, Green \& Co, London.

Henning, W. L. (1939) Prenatal and postnatal sex ratio in sheep. 7. agric. Res. 58, 565.

Hunter, G. L., Adams, C. E. \& Rowson, L. E. A. (1955) Interbreed ovum transfer in sheep. J. agric. Sci. 143 .

LAING, J. A. (1949) Infertility in cattle associated with the death of ova at early stages after fertilization. 7. comp. Path. 59, 97.

Lopyrin, A. I., Loginova, N. V. \& Karpov, P. L. (1950) Experiment in inter-breed transference in sheep. Soviet Zootech. 5, 50.

Lopyrin, A. I., Loginova, N. V. \& Karpov, P. L. (I95I) The effect of changed conditions during embryogenesis on growth and development of lambs. Soviet Zootech. 6, 83 . 
Moore, N. W. \& Rowson, L. E. A. (I959) Maintenance of pregnancy in ovariectomized ewes by means of progesterone. Nature, Lond. 184, Suppl. 18, p. 14 10.

Quinzan, J. \& MARE, G. S. (1931) XVIIth Rep. vet. Res. S. Afr. p. 663.

Robinson, T. J. (I95I) The control of fertility in sheep. Part II. The augmentation of fertility by gonadotrophin treatment of the ewe in the normal breeding season. F. agric. Sci. 4I, 6.

TANABE, T. Y. \& CASIDA, L. E. (1949) The nature of reproductive failures in cows of low fertility. $\mathcal{J}$. Dairy Sci. 32, 237.

UNDERWOOD, E. J. \& SHIER, F. L. (1941) Studies in sheep husbandry in Western Australia. I. The effect of flushing on fertility. F. Dep. Agric. W. Aust. 18, 13.

Walton, A. (1958) Artificial insemination in retrospect and prospect. F. R. agric. Soc. 119, 63.

WARWICK, B. L. \& BERRY, R. O. (1949) Intergeneric and intraspecific embryo transfers. F. Hered. 40, 297.

WARWICK, B. L., BERRY, R. O. \& HoRLACHER, W. R. (1934) Results of mating rams to angora female goats. Rec. Amer. Soc. Anim. Prod. p. 225.

\section{Appendix}

\section{R. V. SHORT}

It has been postulated that early embryonic death in a number of species of domestic animals may be due to a deficiency of progesterone. This theory receives some support from the fact that in cattle (Laing, I949; Hawk, Wiltbank, Kidder \& Casida, I955), sheep (Robinson, I95I) and pigs (Robertson, Casida, Grummer \& Chapman, I95I; Perry, 1954), the peak incidence of embryonic mortality occurs at about the time when the corpus luteum would be beginning to regress if the animal were not pregnant. Progesterone therapy has been used in cattle in an attempt to correct this deficiency, and different workers have claimed widely differing degrees of success from such treatment (Herrick, 1953; Dawson, 1954; Wiltbank, Hawk, Kidder, Black, Ulberg \& Casida, I956; Johnson, 1958).

During the course of the experiments described above by Moore \& Rowson, a unique opportunity arose to investigate the blood progesterone levels in groups of ewes with varying amounts of embryonic mortality. It was also of great interest to find out if superovulation was capable of raising the blood progesterone level, and thus providing a very efficient form of endogenous progesterone therapy.

\section{MATERIAL AND METHODS}

Samples of about a litre of blood were obtained from the jugular veins of Suffolk ewes on the $15^{\text {th }}$ day of pregnancy. These animals were representative of each of the $N_{2}, N_{5}, S_{2}$ and $S_{5}$ groups described above, and they were all slaughtered on Day $\mathrm{I} 8$, at which time counts were made of the number of embryos and corpora lutea that were present.

The blood was prevented from clotting by the addition of sodium oxalate crystals, and after centrifugation the plasma was taken off and stored at $-15^{\circ} \mathrm{C}$ until it could be assayed. The assay procedure was carried out exactly as described previously (Short, 1958), and the results have not been corrected for extraction losses. In addition to progesterone, it was also possible to measure 20๔-hydroxypregn-4-en-3-one in each of the plasma samples. 


\section{RESULTS}

The results are shown in Table $\mathrm{I}$ 2. It is clear that superovulation caused a significant increase in the blood hormone levels; the mean concentrations in the

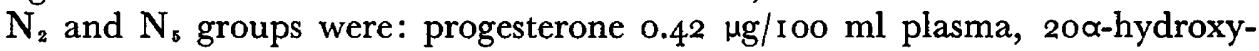
pregn-4-en-3-one $0.44 \mu \mathrm{g} / \mathrm{roo} \mathrm{ml} \mathrm{plasma,} \mathrm{and} \mathrm{these} \mathrm{are} \mathrm{in} \mathrm{close} \mathrm{agreement} \mathrm{with}$ the concentrations found in a previous study (Short \& Moore, 1959). In the $S_{2}$ and $S_{5}$ groups on the other hand, the mean values were: progesterone $\mathrm{I} .08 \mathrm{\mu g} / \mathrm{I}$ oo $\mathrm{ml}$ plasma, 20 $\alpha$-hydroxypregn-4-en-3-one $\mathrm{I} . \mathrm{I} 5 \mathrm{\mu g} / \mathrm{I} 00 \mathrm{ml}$ plasma.

\section{TABLE 12}

BLOOD PROGESTERONE AND 2O๔-HYDROXYPREGN-4-EN-3-ONE LEVELS IN THE PERIPHERAL BLOOD OF NORMAL AND SUPEROVULATED EWES ON THE I 5 TH DAY OF PREGNANCY

\begin{tabular}{|c|c|c|c|c|}
\hline \multirow[b]{2}{*}{$\begin{array}{c}\text { Experimental } \\
\text { group }\end{array}$} & \multirow[b]{2}{*}{$\begin{array}{l}\text { Animal } \\
\text { No. }\end{array}$} & \multirow[b]{2}{*}{$\begin{array}{c}\text { No. corpora } \\
\text { lutea }\end{array}$} & \multicolumn{2}{|c|}{$\mu \mathrm{g} / \mathrm{I}$ oo $\mathrm{ml}$ plasma } \\
\hline & & & Progesterone & $\begin{array}{c}20 \alpha- \\
\text { hydroxypregn- } \\
\text { 4-en-3-one }\end{array}$ \\
\hline $\mathrm{N}_{2}$ & $\begin{array}{l}1 \\
2 \\
3\end{array}$ & $\begin{array}{l}3 \\
2 \\
2\end{array}$ & $\begin{array}{l}0.44 \\
0.4^{8} \\
0.5^{\circ}\end{array}$ & $\begin{array}{l}0.49 \\
0.32 \\
0.5^{8}\end{array}$ \\
\hline $\mathrm{N}_{\mathrm{b}}$ & $\begin{array}{l}4 \\
5 \\
6 \\
7\end{array}$ & $\begin{array}{l}2 \\
3 \\
2 \\
3\end{array}$ & $\begin{array}{l}0.30 \\
0.49 \\
0.28 \\
0.42\end{array}$ & $\begin{array}{l}0.45 \\
0.50 \\
0.42 \\
0.29\end{array}$ \\
\hline $\mathrm{S}_{2}$ & $\begin{array}{r}8 \\
9 \\
\text { IO } \\
\text { I I }\end{array}$ & $\begin{array}{r}15 \\
7 \\
13 \\
16\end{array}$ & $\begin{array}{l}0.73 \\
1.28 \\
1.18 \\
1.49\end{array}$ & $\begin{array}{l}1.06 \\
1.36 \\
1.00 \\
1.60\end{array}$ \\
\hline $\mathrm{S}_{5}$ & $\begin{array}{l}12 \\
13 \\
14 \\
15\end{array}$ & $\begin{array}{r}10 \\
10 \\
4 \\
7\end{array}$ & $\begin{array}{l}0.80 \\
1.70 \\
0.35 \\
1.14\end{array}$ & $\begin{array}{l}0.90 \\
1.86 \\
0.60 \\
0.82\end{array}$ \\
\hline
\end{tabular}

The results are not corrected for extraction losses.

$\mathrm{N}_{2}=$ Normal recipients with two fertilized ova.

$\mathrm{N}_{5}=$ Normal recipients with five fertilized ova.

$\mathrm{S}_{2}=$ Superovulated recipients with two fertilized ova.

$S_{5}=$ Superovulated recipients with five fertilized ova.

The average number of corpora lutea in the $N_{2}$ and $N_{5}$ groups was 2.4 per animal, whereas in the $S_{2}$ and $S_{5}$ groups it was 10.3 per animal. Thus, a fourto fivefold increase in the number of corpora lutea produced a two- to threefold increase in the blood hormone levels.

Since Moore \& Rowson established that the percentage embryonic mortality was greatest in the $N_{5}$ and $S_{5}$ groups, and these results show that the progesterone levels are highest in the $S_{2}$ and $S_{5}$ groups, it is therefore obvious that, under the conditions of this experiment, embryonic mortality could not have been due to a progesterone deficiency.

It is interesting to note that even in the superovulated animals the progesterone : 20 $\alpha$-hydroxypregn-4-en-3-one ratio remained constant at about 
I : I. The same ratio is found in normal ewes during the oestrous cycle and throughout pregnancy (Short \& Moore, 1959), and it suggests that no marked changes are occurring in the rate of progesterone metabolism.

\section{REFERENCES}

Dawson, F. L. M. (I954) Progesterone in functional infertility of cattle. Vet. Rec. 66, 324.

Hawk, H. W., Wiltbank, J. N., KiddeR, H. E. \& Casida, L. E. (I955) Embryonic mortality between 16 and 34 days post-breeding in cows of low fertility. 7. Dairy Sci. 38, 673 .

HeRrICK, J. B. (1953) Clinical observations of progesterone therapy in repeat breeding heifers. Vet. Med. 48,489 .

JoHNSON, K. R. (1958) Effect of I 7 $\alpha$-hydroxyprogesterone I 7-n-caproate on the reproductive performance of cattle. Ann. N.Y. Acad. Sci. 71, 577.

LAING, J. A. (I 949) Infertility in cattle associated with death of ova at early stages after fertilization. $\mathcal{7}$. comp. Path. 59, 97.

Perry, J. S. (1954) Fecundity and embryonic mortality in pigs. 7. Embryol. exp. Morph. 2, 308.

Robertson, G. L., Casida, L. E., Grummer, R. H. \& Chapman, A. B. (195I) Some feeding and management factors affecting age at puberty and related phenomena in Chester White and Poland China gilts. 7. Anim. Sci. 10, 84 I.

Robinson, T.J. (I951) The control of fertility in sheep. Part II. The augmentation of fertility by gonadotrophin treatment of the ewe in the normal breeding season. F. agric. Sci. 41, 6 .

Short, R. V. (I958) Progesterone in blood. I. The chemical determination of progesterone in peripheral blood. 7. Endocrin. 16, 415.

Short, R. V. \& Moore, N. W. (1959) Progesterone in blood. V. Progesterone and 20 2 -hydroxypregn4-en-3-one in the placenta and blood of ewes. F. Endocrin. 19, 288.

Wiltbank, J. N., Hawk, H. W., Kidder, H. E., Bl.ack, W. G., Ulberg, L. G. \& Casida, L. E. (I956) Effect of progesterone therapy on embryo survival in cows of lowered fertility. $\mathcal{F}$. Dairy Sci. 39, 456. 